\title{
Communicating with Transculturation
}

\author{
Elfriede Hermann
}

\section{(2) OpenEdition}

Journals

Electronic version

URL: http://journals.openedition.org/jso/980

DOI: $10.4000 /$ jso. 980

ISSN: $1760-7256$

\section{Publisher}

Société des océanistes

\section{Printed version}

Date of publication: 1 December 2007

Number of pages: $257-260$

ISBN: 978-2-85430-010-9

ISSN: 0300-953x

\section{Electronic reference}

Elfriede Hermann, «Communicating with Transculturation », Journal de la Société des Océanistes [Online], 125 | Année 2007-2, Online since 01 December 2010, connection on 01 May 2019. URL: http://journals.openedition.org/jso/980 ; DOI : 10.4000/jso.980 


\title{
Communicating with Transculturation ${ }^{1}$
}

by

\author{
Elfriede HERMANN*
}

KEYwords: transculturation, Cuban history, exchange, Ngaing (Papua New Guinea), Banabans (Fiji)

Transculturation is fundamentally involved in the formation and continuous shaping of cultures. For this discussion, I have slightly modified the original concept, as developed by Fernando Ortiz ([1947] 1995), to mean the adoption of cultural practices and their socio-cultural recontextualization. What's more, this recontextualization involves a conceptualization, which is, at once, a reconceptualization, in that the meaning of the adopted aspects is combined with the discourses of the recipient culture. The process of transculturation «is a phenomenon of the contact zone», to use the graphic phrase of Mary Louise Pratt (1992: 6). Nor should we conceive this process as something that only occurs in the recipient culture (or the recipient group). Rather what we have is a "two-way borrowing and lending between cultures», as Renato Rosaldo (1995: Xv) summed up. From this observation we may conclude that also the socio-cultural configuration from which something is borrowed the donor culture, as it were - does not remain uninfluenced by the transaction to which it is party. Thus the concept of «transculturation»
MoTS-CLÉs : transculturation, histoire cubaine, échanges, Ngaing (Papouasie Nouvelle-Guinée), Banabans (Fidji) recognizes that the process per se stems from social interactions and the power relationships these involve.

The concept of «transculturation» was coined by the Cuban sociologist Fernando Ortiz ([1947] 1995). In his book on the history of tobacco and sugar in Cuba indeed he deliberately created it as a neologism. Ortiz gave the chapter where he introduces his concept of transculturation the following title:

"On the Social Phenomenon of "Transculturation" and Its Importance in Cuba.» (Ortiz, 1995: 97)

Drawing on his case study of Cuba, he pointed out that when cultures encounter each other, each of the parties invariably exerts a strong influence on the other(s) (Ortiz, 1995: 100). Ortiz makes clear, in the course of reviewing Cuba's history, that oppressors and oppressed alike were all locked in a «painful process of transculturation» (Ortiz, 1995: 102). He showed that often enough force of a physical and mental kind was exercised, and alerted his readers to the way power relationships were always, at bottom,

${ }^{1}$ Participated into this session: Emmanuelle Crane \& Grant McCall, Jean De Lannoy, Adi Hastings, Junko Edo, Emma Gilberthorpe, Elfriede Hermann, Steffen Herrmann, Lisette Josephides, Mark Mosko, Anton Ploeg, Nancy Pollock, Ropate Qalo, John Taylor, Jaap Timmer, Ghislaine van Maane, Polly Wiessner.

* University of Göttingen, Elfriede.Hermann@phil.uni-goettingen.de. 
implicated in transculturation. It is against the background of his commentary on Cuban history that Ortiz tells us «the process also necessarily involves the loss or uprooting of a previous culture» (Ortiz, 1995: 102).

But he goes on to point out that the concept of transculturation implies «the idea of the consequent creation of new cultural phenomena» (Ortiz, 1995: 102-103). The latter defining component was likewise stressed by Bronislaw Malinowski in the introduction he wrote to the first edition of Ortiz's work.

This concept of transculturation coined by Ortiz opens for us, in any event, valuable perspectives on the matter of transcultural exchange under conditions of unequal power relationships, so stresses Fernando Coronil (1995: XLI-XLIII) in his own introduction to Ortiz's book, which he wrote for the 1995 edition. Coronil (1995: XXXVI-XXXXVIII) notes that Malinowski broke the undertaking he gave Ortiz when borrowing his concept, namely that he would only use it in his sense and always acknowledge its paternity. Coronil points out that only very few anthropologists, literary critics and exponents of cultural studies have so far been willing to seriously address Ortiz' book. Amid those studies that have injected the concept of «transculturation» into contemporary debate a noteworthy study is by Mary Louise Pratt (1992), coming from within literary theory. Also worth mentioning besides the various works cited by Coronil are the following anthropological sources: Rolf Husmann (1984); Gundolf Krüger (1986); Karl Wernhart (2001); Claudia Hirsch (1995); Silvia Spitta (1995); Wolfgang Kempf (2003) und Quetzil Castaneda (2004). It remains to be seen whether this list, which by the way is not at all exhaustive, indicates a growing interest in the concept of transculturation.

As Silvia Spitta (1995: 6) has stressed, the notion of transculturation must «continually be redefined for specific contexts». And as Coronil (1995: XLII) explains, the concept readily lends itself to being thus modified; indeed it has much to offer to anthropology, not least in respect of how interacting anthropological theories are to be conceptualized.

In encyclopedias of anthropology to date, there is little or no point in searching for anything under «transculturation». Does this mean, then, that the concept is not part of the standard terminology of our discipline? And if not, should we not perhaps think of adding it to our familiar repertoire of terms? To answer these questions, we might, for purposes of conceptua- lizing «transculturation» for cultural and social anthropology, try asking some further questions:

- What components in the definition of transculturation are of especial importance in our research?

- What are the merits and demerits of the concept of transculturation?

Aside from the issue of anthropological conceptualization, what we should note, I suggest, is how various societies deal with processes of transculturation. For in order to conceptualize these, they have naturally developed terms of their own. They have at their disposal cultural rules of transfer; and they negotiate their cultural logic more or less explicitly in interaction with others.

\section{Problems of indigenous conceptualizations of transculturation. Two examples, the Ngaing of Papua New Guinea and the Banabans of Fiji}

That societies in Oceania do conceptualize processes of adopting alien cultural elements into their own culture and of transferring to cultural others elements of theirs, dawned on me during my fieldwork, first, with the Ngaing of Papua New Guinea and, second, with the Banabans of Fiji. Their respective conceptualizations are present, and assume relevance, in the actions they perform, even if this is often more implicit than overt.

Older men and women among the Ngaing in Papua New Guinea affirmed, to take one example, that a man called Yali, who at one time spearheaded a social movement in Madang Province, had adopted this or that practice from European culture. Thus Yali had, among other things, picked up the idea of laying out villages in an orderly way while travelling in Australia, an idea he then followed up upon returning to his home region (Hermann, 1995: 90-91). From the narratives of the Ngaing it is apparent that Yali had assumed (no less, by the way, than the Ngaing had) that Australian culture was offering itself to Papua New Guineans for transfer - for what other motive could the Australians have had for bringing Yali to Australia, if not to show him everything they had? Yali, I was told, operated on the assumption that the Australians had promised them a similar lifestyle to that in Australia. But when the colonial masters saw the amount of power Yali had amassed, they did their best to weaken his power (Hermann, 1995: 118). The older men and women know that 
alongside the influence the Australians had on Yali stands the impression that Yali had on the Australians. This knowledge they pass on to the younger generations, to the extent that it is in the present of relevance to the latter.

The Banabans, a people originally from the island of Banaba (part of «Micronesia») who were relocated in 1945 to Rabi Island in Fiji, were in the habit of alluding, when telling me of their contemporary culture, to exchanges of cultural practices as having taken place with other ethnic groups living in Fiji. What they repeatedly mentioned, for example, was a two-way process of borrowing each other's foodstuffs or recipes. Fijians from the neighbouring islands, they liked to tell me, had taken over from the Banabans the practice of eating raw fish te ika ae e menaai, "fish that is fresh» as the Banabans call it. Prior to their coming, the Banabans say, the Fijians were in the habit of eating their fish uncooked only if first marinated in lemon juice, coconut milk, chili or vegetables - a recipe the Fijians know as kokoda. Only at a later date did I learn that an «ex-change» had occurred here in the true sense of the word:

«After staying with the Fijians for sixty years, we have learnt how to prepare kokoda which we now call miti and Fijians in areas close to Rabi (Vanua Levu and Taveuni) have learnt that the best way to eat fish is by eating it as it is.» (Nei Miri and $\mathrm{Na}$ Toki, 15.02.1998)

Let me just add in passing that miti is itself a Fijian word that the Banabans have «transcultured». Miti refers to foodstuffs (apart from fish) marinated in uncooked coconut milk. In any event, the Banabans deem food a domain eminently suited to cultural exchange.

The Banabans are highly aware of these cultural adoptions of theirs:

«We have taken on new cultures, some part of the cultures that we live in»

as Na Tom put it incisively (13.11.1997). And Nei Rebo declared:

«Because they [the Banabans] are now living in the Fijians' land. So they communicate, they make friends, so they exchange!» (18.02.2005)

\section{Questions on indigenous conceptualization}

Let me wind up this introduction of mine by reviewing several questions on the indigenous conceptualization of transculturation, questions that possibly merit our closer attention:

- How do Oceanian societies conceptualize proces- ses such as cultural borrowing, incorporation, and exchange? Or more exactly:

- How do members of a society see it when elements from other cultures are adopted into their own culture?

- How do they see it when elements from their own culture are transplanted into other cultures?

- To what extent do people living in Oceania distinguish between discrete contexts of transculturation?

- What is defined as transferable or non transferable and under what conditions?

- And the last question is this: Can we when comparing the conceptualizations of different groups identify any common ground?

In terms of the far-ranging topic of our conference, Pacific Challenges: Questioning Concepts, Rethinking Conflicts, another possible question would be to ask:

- What role is attributed to processes of cultural adoption in the genesis of conflicts?

- Does transculturation contribute to conflict resolution and intercultural communication - and if so, to what extent?

I would assume, based on what the Ngaing and the Banabans told me, that in every society a certain culturally specific consensus can be found on three questions:

a) on the processes of transfer;

b) on the agents doing the transferring; and

c) on the knowledge that is transferred.

a) On the question of processes, we find that social groups have developed specific rules governing the transfer of cultural aspects - for example, rules about taking but also about giving, rules about recognizing sources and origins, rules about the extent to which something may be transferred, rules about the domains in which transfer is permissible and the domains where it is not.

b) As for the agents, what we might expect to find are culturally specific ideas on how members of the society in question are expected to deal with novelty should they retain the new in the form in which it presents itself or should they combine it with what is already there?

c) With regard to knowledge, there prevails, it might be argued, in some societies a certain consensus on whether knowledge of a specific transfer should be kept alive across a specific phase of time or may instead be forgotten.

\section{BIBLIOGRAPHY}

BARFIELD Thomas (ed), 1997. The Dictionary of Anthropology, Oxford, Blackwell Publishers.

BARNARD Alan and Jonathan SPENCER (eds), 1996. Encyclopedia of Social and Cultural Anthropology, London, Routledge. 
Castaneda Quetzil E., 2004. Art-writing in the modern Maya art world of Chichén Itzá. Transcultural ethnography and experimental fieldwork, American Ethnologist 31 (1), pp. 21-42.

Coronil Fernando, 1995. Introduction to the Duke University Press Edition. Transculturation and the Politics of Theory: Countering the Center, Cuban Counterpoint, in F. Ortiz, Cuban Counterpoint: Tobacco and Sugar, Durham and London, Duke University Press, pp. IX-LVI.

Hermann Elfriede, 1995. Emotionen und Historizität. Der emotionale Diskurs über die Yali-Bewegung in einer Dorfgemeinschaft der Ngaing, Papua New Guinea, Berlin, Reimer.

Hirsch Claudia, 1995. Die Bedeutung von Fernando Ortiz im Verständnis der Afrocubanischen Glaubensvorstellungen. Analyse einer Ethnohistorischen Betrachtungsweise. Diplomarbeit zur Erlangung des Magistergrades der Philosophie an der Universität Wien (unpublished).

HusmanN Rolf, 1984. Transkulturation bei den Nuba. Ethnohistorische Aspekte des kulturellen Wandels im 19. und 20. Jahrhundert, Göttingen, Edition Herodot.

KEMPF Wolfgang, 2003. Jenseitsvorstellungen im Wandel - Christentum und Transkulturation bei den Ngaing in der Madang Provinz von PapuaNeuguinea, in W. Köpke and B. Schmelz (eds), Hamburg: Südsee. Expedition ins Paradies, Hamburg, Museum für Völkerkunde, Mitteilungen aus dem Museum für Völkerkunde Hamburg (Neue Folge, Band 33), pp. 375-399.

KRÜGER Gundolf, 1986. “Sportlicher Wettkampf” auf Hawaii. Eine Konfiguration und ihr Wandel als Gegenstand ethnohistorischer Forschung, Göttingen, Edition Herodot.

MaLinowski Bronislaw, [1947] 1995. Introduction, in F. Ortiz: Cuban Counterpoint: Tobacco and Sugar, Durham and London, Duke University Press, pp. LVII-LXIV.

ORTIZ Fernando, [1947] 1995. Cuban Counterpoint: Tobacco and Sugar, Durham and London, Duke University Press (1940 originally published in Spanish).

Pratt Mary Louise, 1992. Imperial Eyes: Travel Writing and Transculturation, London, Routledge.

Rosaldo Renato, 1995. Foreword, in N. G. Canclini, Hybrid Cultures: Strategies for Entering and Leaving Modernity, Minneapolis, University of Minnesota Press, pp. XI-XVII.

SpITta Silvia, 1995. Between Two Waters. Narratives of Transculturation in Latin America, Houston, Rice University Press.

Wernhart Karl R., 2001. Von der Strukturgeschichte zum transkulturellen Forschungsansatz: Ethnohistorie und Kulturgeschichte im neuen Selbstverständnis, in K. R. Wernhart and W. Zips (eds), Ethnohistorie: Rekonstruktion und Kulturkritik: Eine Einführung, Wien, Promedia (2. überarbeitete Auflage), pp. 41-54. 